\title{
Background for Strategic Priorities for Development of Regional Universities
}

\author{
Nataliya Logunova, Tatyana Glechikova \\ dept. economic of Kerch State Maritime Technological University \\ Kerch, Russia \\ natalya_logunova@mail.ru
}

\begin{abstract}
In the paper, based on the expert assessment, the strategic priorities for the development of regional universities are substantiated in the context of reforming the system of higher education in Russia. It has been established that such factors as the improvement of the material and technical base, the improvement of the quality of education and the development of strategic partnership patterns are of the greatest importance for the effective development of the university. Respondents noted that the implementation of the priority "Formation of an innovative educational environment" is possible through the development of a network of core departments, as well as a network of laboratories (centers) of outside organizations, and the creation of business incubators and technology transfer centers.
\end{abstract}

Keywords-strategic; priorities; expert; evaluation; regional university; efficiency

\section{INTRODUCTION}

The key focus of the implementation of the governmental policy is to increase the efficiency and quality of education that ensures the preservation and reproduction of the basic values of the society and acts as a catalyst for the development of an innovative economy based on the triad of education science - production. The higher school, which fosters the formation of the intellectual elite, is called upon to provide the society with specialists who can adequately set and solve the tasks of development, introducing innovations, adequately respond to the challenges of the time [1-5].

The reform of the higher education, undertaken in Russia for recent decades, radically changed the conditions for the functioning of higher education institutions. Tougher requirements for the academic process organization and staffing of the educational activities, the reduction in the number of higher educational institutions, as well as the number of students, the main reasons for which were recognition of the activities of universities by the Ministry of Education and Science of the Russian Federation ineffective, as well as a sharp decline in the birth rate and industrial production, changes in demands for the higher education, moral and physical aging of the existing core funds of universities, as well as the lack of the necessary managerial experience and knowledge among the University managers and significant structural imbalances in the development of regions have led to a significant increase in competition and a high level of interregional asymmetry in the provision of educational services.

In addition, the need to achieve the targets and key performance indicators identified in accordance with the monitoring strategy of universities, under the conditions of the extreme limited governmental financial resources allocated and the environmental instability, predetermines the importance of creating an adaptive university management system based on the rationale for the strategic priorities of its development, with taking into account regional determinants and future needs of the country as a whole.

The strategic analysis of the effectiveness of higher education institutions has made it possible to identify the key focuses for the development of regional universities in order to form management decisions at various hierarchical levels.

To substantiate the degree of priority of the key directions of the strategic development of universities, the authors carried out an expert evaluation, the results of which allowed ranking the strategic priorities for the development of universities as their importance diminished.

\section{STRUCTURAL DIAGRAM OF SYSTEM COMPONENTS}

Twenty representatives of the administrative and managerial staff of higher education institutions working in various areas were invited in the expert group. They were arranged into 4 groups of 5 specialists each:

group 1: rectors (directors of institutes) and first vicerectors;

group 2: vice-rectors for research activities and heads of $\mathrm{R}$ \& D departments;

group 3: pro-rectors in economics and finance and chief accountants

group 4: heads of departments (chairs).

The expert evaluation was carried out in several stages (Figure 1) by means of questionnaires of experts and consisted in forming an expert opinion on the importance of ten strategic priorities for the development of universities by assigning them a rank number.

At the same time, the priority assessed as the highest by the expert was ranked 10 . If the expert recognized several 
priorities as equivalent, then they were assigned the same rank numbers, which were subsequently transformed into standardized ones [3, 6-7].

Within the framework of the identified strategic priorities, five criteria were also mentioned that affect the achievement of the stated objectives of the organizations, which were to be ranked on a scale of 1 to 5, where 1 - does not have a significant impact, 5 - influences the implementation of priorities to a greater extent.

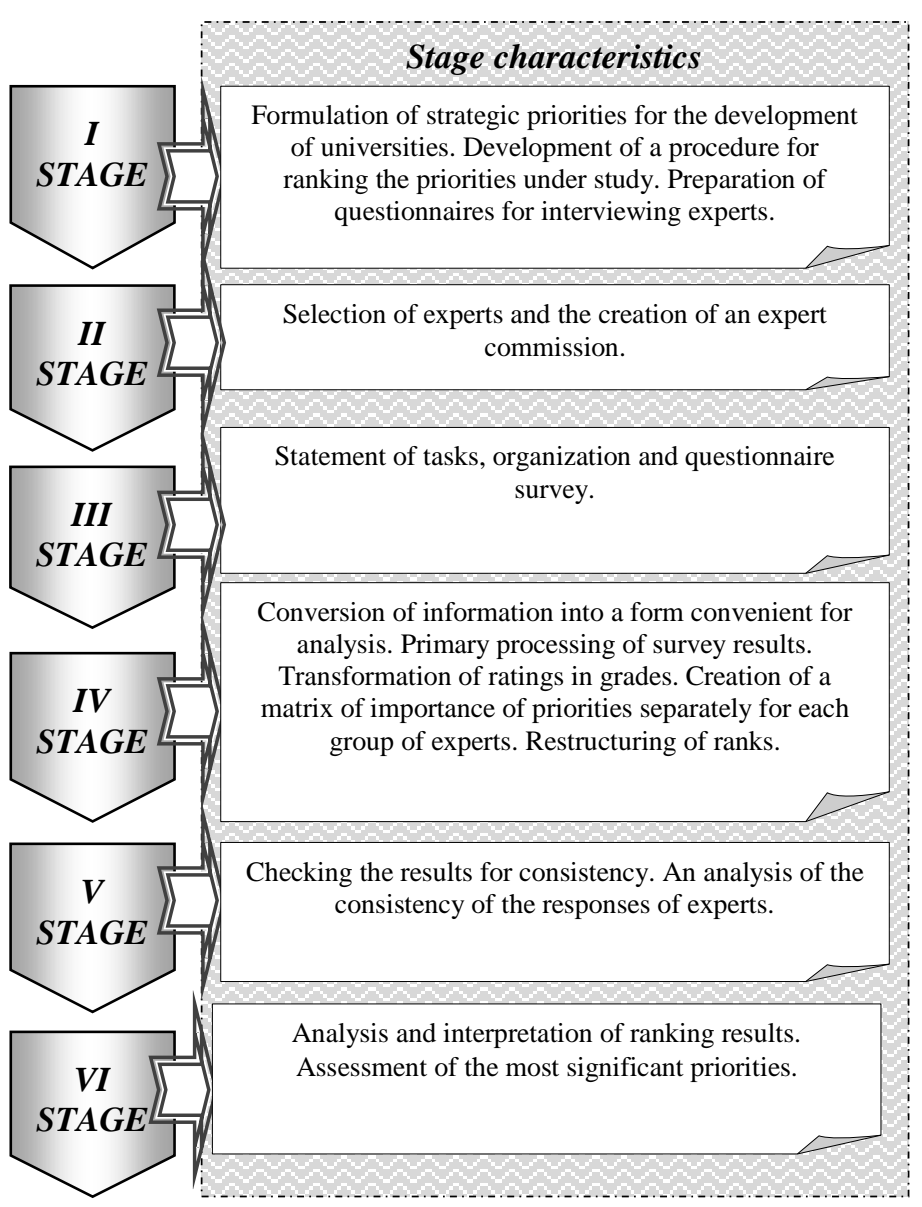

Fig. 1. Evaluation stage

The results of the expert evaluation are given in Tables 1-3 and Fig. 2.
TABLE I THE EVALUATION OF THE STRATEGIC PRIORITIES FOR THE DEVELOPMENT OF THE REGIONAL HIGHER EDUCATION INSTITUTIONS

\begin{tabular}{|c|c|c|c|c|c|c|}
\hline \multirow[b]{2}{*}{ Priorities } & \multirow{2}{*}{$\begin{array}{c}\text { Symbol } \\
\text { of the } \\
\text { priorit } \\
y\end{array}$} & \multicolumn{4}{|c|}{$\begin{array}{c}\text { Average ranks per } \\
\text { expert groups }\end{array}$} & \multirow{2}{*}{$\begin{array}{c}\text { Summa } \\
\text { rized } \\
\text { group } \\
\text { evaluat } \\
\text { ion }\end{array}$} \\
\hline & & $\begin{array}{c}1 \\
\text { gro } \\
\text { up }\end{array}$ & $\begin{array}{c}2 \\
\text { gro } \\
\text { up }\end{array}$ & $\begin{array}{c}3 \\
\text { gro } \\
\text { up }\end{array}$ & $\begin{array}{c} \\
\text { gro } \\
\text { up } \\
\end{array}$ & \\
\hline $\begin{array}{l}\text { I. Increased } \\
\text { effectiveness of career } \\
\text { guidance activity }\end{array}$ & ri 1 & 4.8 & 5.8 & 4.6 & 6.4 & 5.4 \\
\hline $\begin{array}{l}\text { II. Increase in } \\
\text { financial performance } \\
\text { of activities }\end{array}$ & ri2 & 8.2 & 7.6 & 8.8 & 8.6 & 8.3 \\
\hline $\begin{array}{l}\text { III. Achievement of } \\
\text { high results in } \\
\text { scientific and research } \\
\text { activities }\end{array}$ & ri 3 & 7.0 & 8.4 & 6.0 & 5.4 & 6.7 \\
\hline $\begin{array}{l}\text { IV. Improving the } \\
\text { quality of education }\end{array}$ & ri 4 & 9.4 & 9.0 & 8.4 & 8.4 & 8.8 \\
\hline $\begin{array}{l}\text { V. Improving the } \\
\text { facilities and } \\
\text { resources }\end{array}$ & ri 5 & 8.8 & 8.8 & 9.0 & 9.4 & 9.0 \\
\hline $\begin{array}{l}\text { VI. Formation and } \\
\text { development of } \\
\text { human resources }\end{array}$ & ri 6 & 8.0 & 8.2 & 6.8 & 8.2 & 7.8 \\
\hline $\begin{array}{l}\text { VII. Development of } \\
\text { the strategic } \\
\text { partnership patterns }\end{array}$ & ri 7 & 8.0 & 8.4 & 8.8 & 8.8 & 8.5 \\
\hline $\begin{array}{l}\text { VIII. Improvement of } \\
\text { the organizational } \\
\text { structure }\end{array}$ & ri8 & 5.0 & 5.4 & 4.8 & 4.8 & 5.0 \\
\hline $\begin{array}{l}\text { IX. Creation of an } \\
\text { innovative educational } \\
\text { environment }\end{array}$ & ri9 & 3.8 & 7.2 & 6.8 & 6.6 & 6.1 \\
\hline $\begin{array}{l}\text { X. Increase in the } \\
\text { level of demand for } \\
\text { graduates }\end{array}$ & ri 10 & 2.8 & 4.8 & 4.0 & 6.8 & 4.4 \\
\hline
\end{tabular}

Thus, according to experts, the most significant for the university are such areas as improving the facilities and resources, improving the quality of education and developing the strategic partnership patterns.

Great attention should be paid to the growth of the financial performance of the educational institution and the creation of the human resource potential. At the same time, despite the fact that the level of employment of graduates is one of the key indicators of monitoring, all specialists, except heads of departments, gave this priority the last rank. 


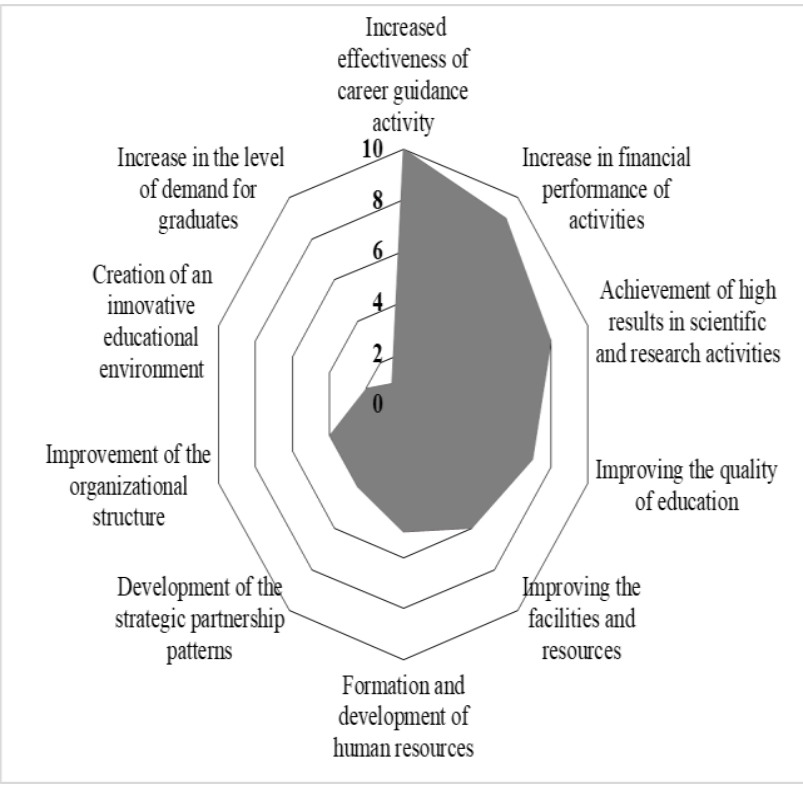

Fig. 2. Graphical interpretation of the expert assessment results on the importance of strategic priorities for the development of a regional university.

\section{TABLE MODELS}

An analysis of the degree of scatter in the opinions of experts showed that the measures for dissipating expert assessments are within the recommended limits (the coefficient of variation does not exceed $33 \%$ by one of the criteria). The most symmetrically distributed responses of experts are on priorities 4 and 5, characterizing the quality of education and the level of facilities and resources of universities.
TABLE I. INDICATORS OF DISPERSED OPINIONS OF EXPERTS

\begin{tabular}{|c|c|c|c|c|c|c|c|c|c|c|}
\hline \multirow[b]{2}{*}{ Indicators } & \multicolumn{10}{|c|}{ Objects of ranking (priorities) } \\
\hline & $\begin{array}{c}r i \\
1\end{array}$ & ri2 & $\begin{array}{c}r i \\
3\end{array}$ & $\begin{array}{r}r i \\
4\end{array}$ & $\begin{array}{c}r i \\
5\end{array}$ & $\begin{array}{r}r i \\
6\end{array}$ & $\begin{array}{c}r i \\
7\end{array}$ & ri8 & $\begin{array}{c}r i \\
9\end{array}$ & $\begin{array}{l}r i \\
10\end{array}$ \\
\hline $\begin{array}{l}\text { Expected } \\
\text { value }\end{array}$ & 5.4 & 8.3 & 6.7 & $\begin{array}{l}8 . \\
8\end{array}$ & $\begin{array}{l}9 . \\
0\end{array}$ & $\begin{array}{l}7 . \\
8\end{array}$ & $\begin{array}{l}8 . \\
5\end{array}$ & 5 & $\begin{array}{l}6 . \\
1\end{array}$ & 4.4 \\
\hline $\begin{array}{l}\text { Standard } \\
\text { error }\end{array}$ & $\begin{array}{l}0.3 \\
36\end{array}$ & $\begin{array}{l}0.2 \\
42\end{array}$ & $\begin{array}{l}0.3 \\
17\end{array}$ & $\begin{array}{l}0 . \\
2 \\
3 \\
6\end{array}$ & $\begin{array}{l}0 . \\
2 \\
1 \\
8\end{array}$ & $\begin{array}{l}0 . \\
3 \\
8 \\
1 \\
\end{array}$ & $\begin{array}{l}0 . \\
3 \\
1 \\
2\end{array}$ & $\begin{array}{l}0.2 \\
05\end{array}$ & $\begin{array}{l}0 . \\
40 \\
3\end{array}$ & $\begin{array}{l}0.3 \\
28\end{array}$ \\
\hline Median value & 5 & 8.5 & 6.5 & 9 & 9 & 8 & 9 & 5 & 6 & 4.5 \\
\hline Mode & 5 & 9 & 5 & $\begin{array}{l}1 \\
0\end{array}$ & $\begin{array}{l}1 \\
0\end{array}$ & 9 & $\begin{array}{l}1 \\
0\end{array}$ & 5 & 8 & 4 \\
\hline $\begin{array}{l}\text { Standard } \\
\text { deviation }\end{array}$ & $\begin{array}{l}1.5 \\
01\end{array}$ & $\begin{array}{l}1.0 \\
81\end{array}$ & $\begin{array}{l}1.4 \\
18\end{array}$ & $\begin{array}{l}1 . \\
0 \\
5 \\
6\end{array}$ & $\begin{array}{l}0 . \\
9 \\
7 \\
3\end{array}$ & $\begin{array}{l}1 . \\
7 \\
0 \\
4\end{array}$ & $\begin{array}{l}1 . \\
3 \\
9 \\
5\end{array}$ & $\begin{array}{l}0.9 \\
18\end{array}$ & $\begin{array}{l}1 . \\
80 \\
4\end{array}$ & $\begin{array}{l}1.4 \\
65\end{array}$ \\
\hline Dispersion & $\begin{array}{l}2.2 \\
53\end{array}$ & $\begin{array}{l}1.1 \\
68\end{array}$ & $\begin{array}{l}2.0 \\
11\end{array}$ & $\begin{array}{l}1 . \\
1 \\
1 \\
6\end{array}$ & $\begin{array}{l}0 . \\
9 \\
4 \\
7\end{array}$ & $\begin{array}{l}2 . \\
9 \\
0 \\
5\end{array}$ & $\begin{array}{l}1 . \\
9 \\
4 \\
7\end{array}$ & $\begin{array}{l}0.8 \\
42\end{array}$ & $\begin{array}{l}3 . \\
25 \\
3\end{array}$ & $\begin{array}{l}2.1 \\
47\end{array}$ \\
\hline Excess & $\begin{array}{l}- \\
0.7 \\
86\end{array}$ & $\begin{array}{l}3.5 \\
98\end{array}$ & $\begin{array}{l}- \\
1.1 \\
17\end{array}$ & $\begin{array}{l}- \\
1 . \\
3 \\
1 \\
2\end{array}$ & $\begin{array}{l}- \\
1 . \\
1 \\
2 \\
5\end{array}$ & $\begin{array}{l}2 . \\
1 \\
4 \\
2\end{array}$ & $\begin{array}{l}- \\
0 . \\
6 \\
2 \\
0\end{array}$ & $\begin{array}{l}0.5 \\
36\end{array}$ & $\begin{array}{l}- \\
0 . \\
67 \\
1\end{array}$ & $\begin{array}{l}- \\
0.7 \\
21\end{array}$ \\
\hline $\begin{array}{l}\text { Asymmetry } \\
\text { ratio }\end{array}$ & $\begin{array}{l}0.1 \\
62\end{array}$ & $\begin{array}{l}- \\
1.5 \\
06\end{array}$ & $\begin{array}{l}0.3 \\
47\end{array}$ & $\begin{array}{l}- \\
0 . \\
1 \\
5 \\
5\end{array}$ & $\begin{array}{l}- \\
0 . \\
3 \\
8 \\
1\end{array}$ & $\begin{array}{l}- \\
1 . \\
2 \\
8 \\
4\end{array}$ & $\begin{array}{l}- \\
0 . \\
6 \\
4 \\
6\end{array}$ & $\begin{array}{l}0.0 \\
00\end{array}$ & $\begin{array}{l}- \\
0 . \\
34 \\
5\end{array}$ & $\begin{array}{l}- \\
0.2 \\
27\end{array}$ \\
\hline $\begin{array}{l}\text { Range of } \\
\text { variability }\end{array}$ & 5 & 5 & 4 & 3 & 3 & 7 & 4 & 4 & 6 & 5 \\
\hline $\begin{array}{l}\text { Coefficient } \\
\text { of variation, } \\
\%\end{array}$ & $\begin{array}{l}6.2 \\
1\end{array}$ & $\begin{array}{l}2.9 \\
1\end{array}$ & $\begin{array}{l}4.7 \\
3\end{array}$ & $\begin{array}{l}2 . \\
6 \\
8\end{array}$ & $\begin{array}{l}2 . \\
4 \\
2\end{array}$ & $\begin{array}{l}4 . \\
8 \\
9\end{array}$ & $\begin{array}{l}3 . \\
6 \\
7\end{array}$ & $\begin{array}{l}4.1 \\
0\end{array}$ & $\begin{array}{l}6 . \\
61\end{array}$ & $\begin{array}{l}7.4 \\
5\end{array}$ \\
\hline
\end{tabular}

TABLE II. ASSESSING THE DEGREE OF CONSENSUS AMONG EXPERTS

\begin{tabular}{|l|c|c|c|c|c|}
\hline \multicolumn{1}{|c|}{ Indices } & $\begin{array}{c}\mathbf{1} \\
\text { grou } \\
\mathbf{p}\end{array}$ & $\begin{array}{c}\mathbf{2} \\
\text { grou } \\
\mathbf{p}\end{array}$ & $\begin{array}{c}\mathbf{3} \\
\text { grou } \\
\mathbf{p}\end{array}$ & $\begin{array}{c}\mathbf{4} \\
\text { grou } \\
\mathbf{p}\end{array}$ & $\begin{array}{c}\text { Summarized } \\
\text { group } \\
\text { estimate }\end{array}$ \\
\hline Matrix average rank & 27.5 & 27.5 & 27.5 & 27.5 & 110 \\
\hline $\begin{array}{l}\text { Variations as for the } \\
\text { average rank }\end{array}$ & 1465 & 1379 & 1241 & 1391 & 21061 \\
\hline $\begin{array}{l}\text { Kendall's concordance } \\
\text { coefficient }\end{array}$ & 0.81 & 0.68 & 0.77 & 0.80 & 0.67 \\
\hline Pearson criterion (actual) & $\begin{array}{c}36.4 \\
9\end{array}$ & $\begin{array}{c}30.6 \\
0\end{array}$ & $\begin{array}{c}34.7 \\
5\end{array}$ & $\begin{array}{c}35.8 \\
6\end{array}$ & 119.89 \\
\hline $\begin{array}{l}\text { The Pearson criterion } \\
\text { (tabular, at 1\% } \\
\text { significance level) }\end{array}$ & 16.9 & 16.9 & 16.9 & 16.9 & 16.92 \\
2 & 2 & 2 & 2 & \\
\hline
\end{tabular}

It should be noted that the largest scale of the variation is marked by the priority "Formation and development of human resources" from the maximum score of "10 points" to "3 points", which is due to the ambiguous importance of this criterion for various groups of experts. However, in the assessments of specialists, values above the average level of 7.8 points prevail. The assessment of the consistency degree in the opinions of experts showed that the opinions of the rectors (directors of institutes) and the first vice-rectors (the concordance ratio was 0.81 ) were most coordinated, as well as among the heads of the departments (the concordance coefficient is 0.80). The least unanimity of opinions was recorded in the group of $\mathrm{R} \& \mathrm{D}$ specialists [7-11]. 
Considering the priorities in the context of their key components, it should be noted that each of them has its most significant factors that form the success of the development of a particular type of the university activities.

Thus, in assessing the effectiveness of career guidance activity, the greatest attention should be given to interaction with the regional employers in the organization of students' industrial training (contracts with organizations, enterprises and governmental structures) and conducting an active advertising campaign in the media (newspapers, magazines, Internet resources, groups in social networks, interviews with alumni, teaching staff and management of the university).

The increase in the financial performance of the universities of the republic is directly related to the orientation of the heads of departments to find additional sources of financing (fundraising) and optimize the structure of expenditures by ensuring targeted and effective use of facilities, labor and financial resources. It is these factors that received the highest assessments of experts.

\section{THE BASIS OF THE STRUCTURAL OBJECT OF MANAGEMENT}

According to respondents' answers, achievement of high $R \& D$ results is possible by creating an infrastructure for the commercialization of research and development, as well as the initialization of a network of science-intensive small innovative enterprises and business projects at universities.

In its turn, the formation of an effective system of practical (project-oriented) training at the university on the basis of centers of applied qualifications and practical training and the creation of new competitive educational programs that meet regulatory requirements and the requirements of professional standards, including those for the supplementary education system and demand of enterprises in the real sector of the economy, will contribute to solving one of the highest priorities of higher education - increase in the quality of education [5, 12-15].

Experts noted that the improvement of the facilities and resources of higher education institutions should be carried out, first of all, through the construction, capital and current repair of buildings and structures, as well as the creation of a comprehensive security system for the university (video surveillance, alarm system, fire protection, and anti-terrorism security). The increase in reliability and the reduction in the energy intensity of educational, social and administrative complexes is of no less importance. At the same time, the experts attributed the improvement of living conditions and pastime of students to less important tasks, the solution of which requires an integrated approach and presupposes a feedback between the direct participants of the educational process and the administration of universities.

In assessing the components that determine the formation and development of the human resources capacity of the university, according to experts, such factors as raising the social status and material well-being of lecturers and university employees (2/3 experts ranked this criterion as the highest rating) and implementing an effective contract mechanism with scientific and teaching staff are especially noteworthy. The respondents showed the least interest in attracting talented specialists from other subjects of the Russian Federation and foreign countries to work at the university. It is suggested that for the development of the university the available personnel potential should be made the best use of by creating favorable conditions for employees for personal and professional growth, including stimulating academic mobility of university employees.

It should be noted that in the current conditions of functioning of higher education institutions, strategic partnership is one of the significant sources of improving the quality of professional training of students and attracting additional funds to develop key activities of the university. Experts identified the following most promising forms of strategic partnership: the development of public-private partnerships (the average score is 4.15 points out of 5 possible); organization of targeted training, retraining of specialists in demanded professions (3.90 points); implementation of technical, research and production tasks with the involvement of leading teachers and students, joint development of standards and programs in the field of vocational education and retraining, satisfying both the current economic needs and the promising areas of development (3.20 points). The establishment of endowment funds at the university and the participation of universities in the creation and development of regional systems of cluster type specialists have put 3.15 and 3.00 points respectively.

Despite the fact that in the ranking, the factor "Improving the organizational structure" was placed on the penultimate place, such component as "ensuring reliable (uninterrupted) functioning of the university management system", 14 experts awarded the highest score (average score is 4.55 points). Attention was paid to the specialists and the importance of forming an entrepreneurial university and optimizing its structure, inter alia, by reducing inefficient educational, research, management and business departments, as well as abolishing duplicating functions in the existing structure of the university.

As a matter of the expert evaluation for the formation of a set of measures to ensure the strategic development of the universities in the Republic of Crimea and the proper distribution of priorities, the most significant factors that contributed to the effective development of higher education institutions were identified by the author using the $\mathrm{ABC}$ method. The following condition was taken into account:

A - the most important factors that comprehensively ensure the achievement of the goals of the universities, according to the ranking assessed in the range from 4.2 to 5.0 points;

B - second-rate factors that are of particular importance for the development of certain areas of activity of higher education institutions and are the supporting elements of the main factors, assessed from 3.6 to 4.2 points;

C - insignificant factors that allow achieving the desired results only in combination with the two previous groups, evaluated by experts below 3.6 points. 
Table 4 demonstrates the ranking of the parameters of the strategic development of higher education in terms of their importance (the most important factors (A) and second-rate factors (B), targeting at which will not only preserve the accumulated potential, overcome the demographic gap and budget deficit, but also take a heading to improve the quality of the educational services and further comprehensive development of universities.

TABLE III. RANKING OF THE FACTORS DETERMINING THE EFFECTIVE DEVELOPMENT OF REGIONAL UNIVERSITIES

\begin{tabular}{|c|c|}
\hline Factors & Mean score \\
\hline 1 & 2 \\
\hline Raising the level of students' practical training & 4.90 \\
\hline Increase of the social status and material well-being of lecturers and employees of university & 4.60 \\
\hline Creation of infrastructure for the commercialization of research and development & 4.55 \\
\hline $\begin{array}{l}\text { Improvement of the facilities and resources for the educational process through the construction, capital repair and maintenance of } \\
\text { buildings and structures }\end{array}$ & 4.55 \\
\hline Ensuring a reliable (uninterrupted) functioning of the university management system & 4.55 \\
\hline $\begin{array}{l}\text { Creation of a system of integrated security of the University (video surveillance systems, alarm systems, fire protection, antiterrorism } \\
\text { security) }\end{array}$ & 4.35 \\
\hline $\begin{array}{l}\text { Interaction with regional employers in the organization of student on-the-job training (contracting with organizations, enterprises and } \\
\text { government agencies) }\end{array}$ & 4.30 \\
\hline $\begin{array}{l}\text { Formation of an effectively functioning system of practical (project-oriented) education at the university on the basis of centers of } \\
\text { applied qualifications and practical training }\end{array}$ & 4.30 \\
\hline Increase of reliability and reduction of energy intensity of educational, social and administrative complexes & 4.20 \\
\hline $\begin{array}{l}\text { Aiming of the department heads at finding additional sources of funding (fundraising); including incomes from the training, } \\
\text { internships, refresher courses and retraining of personnel; rendering of fee-based consulting services of organizational, informational, } \\
\text { marketing, financial and analytical nature using the objects of the innovative infrastructure of the university in the functional areas of } \\
\text { the relevant divisions }\end{array}$ & 4.15 \\
\hline Extension of public and private partnership (P3) as a strategic resource in the development of higher education & 4.15 \\
\hline Implementation of effective contract mechanism with the scientific staff and lectures & 4.10 \\
\hline $\begin{array}{l}\text { Improvement and updating of curricula and programs in accordance with the set of competencies for the university graduate according } \\
\text { to the requirements of employers }\end{array}$ & 4.10 \\
\hline Optimization of the structure of expenditures by ensuring the targeted and efficient use of facilities, labor and financial resources & 4.05 \\
\hline The development of a network of core departments, as well as a network of laboratories (centers) of outside organizations & 4.05 \\
\hline $\begin{array}{l}\text { Formation and development of organizational forms of strengthening cooperation between higher education institutions and the } \\
\text { industry }\end{array}$ & 4.05 \\
\hline $\begin{array}{l}\text { An active advertising campaign (media advertisements - newspapers, magazines, Internet resources, groups in social networks, } \\
\text { interviews with alumni, lecturers and university leaders) }\end{array}$ & 4.00 \\
\hline $\begin{array}{l}\text { Development of new competitive educational programs that meet the legal requirements and the requirements of professional } \\
\text { standards, including for the system of additional education and on demand of enterprises of the real sector of the economy }\end{array}$ & 4.00 \\
\hline Establishment of the "institute" of a reserve of pedagogical, scientific and managerial staff; recruitment agency of teachers/lecturers & 4.00 \\
\hline The initialization of a network of knowledge-intensive small innovative enterprises and business projects at the university & 3.90 \\
\hline Participation of the University in technological platforms and programs of innovative development of AP companies & 3.90 \\
\hline Organization of targeted training, retraining of specialists professions on demand & 3.90 \\
\hline $\begin{array}{l}\text { Stimulation of academic mobility of university employees and students, including the development of internship programs in Russian } \\
\text { and foreign universities, research institutes and enterprises }\end{array}$ & 3.85 \\
\hline Creation of business incubators and technology transfer centers & 3.85 \\
\hline $\begin{array}{l}\text { Improvement of pricing mechanisms for educational services due to the development of a system of benefits, discounts and deferrals } \\
\text { from tuition payment in order to increase the attractiveness of contractual relations }\end{array}$ & 3.65 \\
\hline Development of educational franchising & 3.60 \\
\hline
\end{tabular}

\section{CONCLUSION}

Respondents noted that the implementation of the priority "Formation of an innovative educational environment" is possible through the development of a network of core departments, as well as a network of laboratories (centers) of outside organizations, and the creation of business incubators and technology transfer centers. The development of educational franchising as an instrument providing access to all those who wish to receive quality education by creating educational networks based on information technologies is also of interest.

The greatest deviation in the experts' assessments for general and intra-factorial rankings is fixed by the importance of such a criterion as "Increasing the level of demand for graduates", which took the last position in the overall rating. 
Thus, "increasing the level of practical training of students" received 4.9 points at 5.0 possible, "the improvement and adjustment of curricula and programs in accordance with the set of competencies of the graduate of the university, relevant to the requirements of employers - 4.10 points, and "the formation and development of organizational forms of strengthening cooperation between universities and the industrial sphere"- 4.05 points.

Attention should be paid to the fact that all the priorities above are closely interrelated. Thus, the increase in the effectiveness of career guidance activity directly affects the improvement of financial performance, as this facilitates additional attraction of extra-budgetary sources of funding in the form of contract-based tuition fee. Increasing the level of facilities and resources in universities will allow both to achieve high R\&D outcomes on the account of applied scientific research and will contribute to the growth of financial sustainability of the university by attracting funds from governmental and non-governmental funds for implementing promising scientific projects, and will also improve the quality of education and the demand for the university graduates by forming practical skills for professional activities.

\section{References}

[1] L.I. Evenko, "System approach to management organization", Economics, 1983, 254.

[2] Yu. I. Chernyak, "System analysis in the management of the economy Economics", 1975, 191
[3] R.A. Fatkhutdinov, "Production management: a textbook for universities Banks and stock exchanges", UNITI, 1997, 447.

[4] O.S. Vikhansky, A.I. Naumov, Management, Economist, 2006, 670.

[5] I. Ansoff, "A new corporate strategy", Series: Theory and practice of management, $\mathrm{SPb}$ : Peter, 1999, 416.

[6] M. Mesarovic, Ya. Takahara, General theory of systems: mathematical foundationsM: Mir, 1978, 312

[7] V.N. Burkov, N.A. Korgin, D.A. Novikov, "Introduction to the theory of management of organizational systems", Moskow, 2009, 264

[8] P.F. Drucker, "Tasks of management in the XXI century", Williams, 2003, 127.

[9] G.S. Kuntz, O'Donnell, "Management: a systemic and situational analysis of management functions", Progress, 1981, 250.

[10] N. Logunova, S. Chernyi, A. Semenova, I. Antipenko, "Modeling the development of complex structures on the example of the maritime industry", Eastern-European Journal of Enterprise Technologies, vol. 6, no. 278 , p. 37,2015 .

[11] Z. Boriev, A. Nyrkov, S. Sokolov and S. Chernyi, "Software and hardware user authentication methods in the information and control systems based on biometrics", IOP Conference Series: Materials Science and Engineering, vol. 124, p. 012006, 2016.

[12] S. Chernyi, "Techniques for selecting topology and implementing the distributed control system network for maritime platforms", AKCE International Journal of Graphs and Combinatorics, 2017.

[13] S. Chernyi, A. Zhilenkov, S. Sokolov, A. Nyrkov, "Algorithmic approach of destabilizing factors of improving the technical systems efficiency", Vibroengineering PROCEDIA, vol. 13, pp. 261-265, 2017.

[14] S. Chernyi, N. Logunova and L. Aleksahina, "System analysis for an integrated assessment of the state of transport infrastructure based on the decomposition of components", 2018 IEEE Conference of Russian Young Researchers in Electrical and Electronic Engineering (EIConRus), 2018.

[15] S. Chernyi, "Methods for ensuring fault tolerance of equipment based on reliability theory", 2018 IEEE Conference of Russian Young Researchers in Electrical and Electronic Engineering (EIConRus), 2018. 